\section{AIDS PEDIÁTRICA: AVANÇOS NA PREVENÇÃO E} DIAGNÓSTICO

Mariane Martins de Araújo Stefani, ${ }^{1}$ João Teixeira Alvares $J r .{ }^{3}$ Gisner Alves de Souza Pereira ${ }^{3}$ e Regina Beatriz Bevilacqua Vieira ${ }^{2}$

\section{RESUMO}

A AIDS pediátrica é uma das doenças mais desafiadoras dos últimos tempos, envolvendo aspectos médicos, familiares, sociais e econômicos. A transmissão vertical mãe-filh é responsável pela maioria dos casos de HIV-1 em crianças em todo o mundo, com tendência crescente em decorrência do aumento da transmissão heterossexual e de mulheres em idade reprodutiva infectadas pelo HIV-1. O diagnóstico precoce da infecção perinatal pelo HIV-1 é crucial para introdução de terapia anti-retroviral e de regimes profiláticos para infecçōes oportunistas. O diagnóstico da infecçẩo pelo HIV-1 em crianças é baseado em parâmetros clínicos, imunológicos e virais. Sintomas clínicos relacionados a AIDS estabelecem o diagnóstico, qualquer que seja a idade da criança. Na ausência de sintomas, o diagnóstico de infecção pelo HIV-1 pode ser obtido por testes sorológicos convencionais seriados, que são inicialmente positivos em praticamente todas as crianças expostas ao HIV-1 durante a gestação, devido à transferênćia transplacentária da IgG materna para o feto. O diagnóstico sortaçágico definitivo só pode ser obtido após negativação dos anticorpos maternos, sendo que a persistên de sorologia positiva após 18 meses de idade indica produçâo de anticorpos pela criança infectad pelo HIV-1. Ensaios baseados na deção sido propostos e poderõo sido propostas de anticorpos não são trates nâo foi ainda demonstrado. A presença do HIV-1 pode ser demonstrada direta ou indiretamente por cultura viral, amplificação do material genético do HIV-1 ou por antigenemia p24. A cultura para detecção de HIV-1 é um procedimento laborioso, caro, exige condições máximas de biossegurança e o resultado pode requerer até quatro semanas de cultivo. A pesquisa do antígeno viral p24 é menos sensível do que a cultura, mesmo após dissociação dos imunecomplexos, não devendo ser usada isoladamente para fins de diagnóstico. A amplificação exponencial do material genético do HIV1 pela Reação em Cadeia de Polimerase (PCR) de forma sensível, específica e rápida representa o teste laboratorial mais atraente e promissor tanto para exclusão de infecçāo como para

1 Prof". Titular do Departamento de Microbiologia, Imunologia, Parasitologia e Patologia Geral (MIPP) do Instituto de Patologia Tropical e Saúde Pública (IPTESP) da Universidade Federal de Goiás (UFG); orientadora dos mestrandos.

2 Prof. Adjunto do MIPP- IPTESP- UFG.

3 Alunos do Curso de Mestrado em Medicina Tropical do IPTESP-UFG; área de concentraçäo: Imunologia.

Endereço para correspondência: Rua Delenda Rezende de Melo esq. com 1* Avenida, Setor Universitário. Caixa Postal 131, CEP 74605-050, Goiânia, GO.

Recebido para publicação em 26/06/99.

Vol. 28 (1): 26-40. jan.-jun. 1999
UNITERMOS: HIV. Diagnóstico sorológico e molecular do HIV-1. AIDS pediátrica. Transmissão vertical. PCR.

\section{INTRODUÇÃO}

Os conhecimentos acerca da infecção causada pelo HIV-1 têm avançado a uma velocidade extraordinária. A infecção pelo HIV-1/AIDS é uma doença que até duas décadas atrás era desconhecida, há pouco mais de uma década não possuía tratamento específico e há cinco anos a taxa de transmissão mãe - filho permanecia imutável. Atualmente a infecção pelo HIV-1/AIDS pode ser rapidamente diagnosticada e tratada com eficácia crescente. A partir de 1994, a hipótese de se interromper a transmissão vertical se tornou uma realidade, quando foi demonstrado que o tratamento de gestantes HIV-1 $1^{+}$/AIDS com AZT reduziu a transmissão vertical em dois terços (12).

Entretanto, nenhum destes avanços notáveis poderá ser oferecido aos pacientes HIV infectados, a menos que estes sejam precocemente diagnosticados e a eles seja assegurado o acesso às terapias anti-retrovirais mais modernas.

A infeção pediátrica pelo HIV constitui importante causa de morbidade e mortalidade em crianças infectadas por via perinatal. A AIDS pediátrica representa uma das doenças mais desafiadoras dos tempos modernos com dramáticas repercussōes familiares, sociais, econômicas e médicas. A infecção pelo HIV costuma ser muito mais agressiva em crianças, que em geral se tornam sintomáticas durante o primeiro ano de vida, muito mais rápido que os adultos, que podem permanecer assintomáticos por uma década ou mais $(4,5,52,61,62)$. Em torno de $16 \%$ das crianças infectadas morrem antes do quarto ano de vida. Crianças infectadas pelo HIV-1 costumam apresentar persistentemente alta carga viral, associada com deteriorização do sistema imune e progressão mais rápida para a doença, e menor sobrevida $(34,54)$.

Desde o início da epidemia, o HIV já infectou em torno de 3,8 milhōes de crianças, sendo que 2,7 milhōes já foram a óbito. Estima-se que 1,1 milhōes de crianças vivem com HIV/AIDS em todo o mundo. A cada dia, ocorrem aproximadamente 1.500 casos novos de infecção pediátrica pelo HIV-1, totalizando mais de 500 mil crianças infectadas por ano, a grande maioria destes casos em países em desenvolvimento (64). O aumento da transmissão heterossexual do HIV-1 e do número de mulheres em idade reprodutiva infectadas traz como conseqüência direta um número crescente de crianças infectadas através da via perinatal (3). Além da transmissão 
vertical, a infecção pelo HIV na infância pode ser adquirida por transfusão de produtos sangüíneos contaminados ou por abuso sexual (22).

Sem intervenção profilática adequada, entre 15\%-40\% dos bebês nascidos de mães com $\mathrm{HIV}^{+} /$AIDS podem se tornar infectados $(12,19,51)$. A transmissão vertical mãe-filho pode ocorrer intra-útero, intrapartum $e$ postpartum por aleitamento materno. A maioria dos casos de transmissão perinatal dá-se durante o trabalho de parto ou no momento do parto propriamente dito.

As peças do quebra-cabeça complexo dos fatores maternos envolvidos na transmissão vertical pelo HIV-1 estão sendo encaixadas. A transmissão vertical é considerada um evento multifatorial envolvendo fatores maternos e neonatais. Atualmente são considerados como fatores de risco maternos: 1. clínica - doença sintomática avançada; 2 . imunológico baixos níveis de linfócitos $\mathrm{T} \mathrm{CD}_{4}{ }^{+}$, altos níveis de linfócitos $\mathrm{T} \mathrm{CD}_{8}{ }^{+}(46,56)$; 3. viral - alta carga viral (acima de 50.000 cópias/ml) $(14,33,46,55,56) ; 4$. obstétricos - tempo de ruptura de membranas maior que 4 horas; parto vaginal $(20,28,31,37,60)$. O aleitamento materno constitui um fator de risco adicional $(18,25)$. Recentemente foi demonstrado que a concordância entre mãe e filho, quanto aos alelos do Complexo de Histocompatibilidade Principal Classe I, parece estar associada com aumento da transmissão vertical (30).

Em 1994, um ensaio clínico realizado nos Estados Unidos e na França (ACTG-076) (12) demonstrou que, na ausência de aleitamento materno, o tratamento de gestantes $\mathrm{HIV}^{+} /$AIDS com AZT reduziu o risco de transmissão vertical em dois terços. Este protocolo completo inclui o uso de AZT via oral a partir da décima quarta semana de gestação, por via endovenosa, durante o trabalho de parto sendo extensivo aos recém-nascidos (xarope, via oral) durante as primeiras seis semanas de vida. Este regime foi rapidamente adotado como tratamento padrão nos EUA e no oeste europeu. Graças os esforços do Programa de Controle/AIDS do Ministério da Saúde, o Brasil passou a adotar o protocolo completo ACTG, com distribuição gratuita dos medicamentos para gestantes infectadas e seus filhos. No entanto, devido à sua complexidade e alto custo, esta recomendação não pôde ser implementada na maioria dos países em desenvolvimento. As estratégias e recomendações para a prevenção da transmissão perinatal do HIV-1 são definidas e baseadas principalmente em condições que predominam em países industrializados. Como a maioria das crianças $\mathrm{HIV}^{+} / A I D S$ nascem em circunstâncias bem menos privilegiadas, observamos com freqüência dificuldades em incorporar estes conhecimentos ao uso prático.

Vários estudos avaliaram o efeito de protocolos reduzidos de AZT na transmissão vertical $(7,10)$. Resultados recentes de 1999 , de ensaios duplo-cego placebo controlados realizados na Tailândia e na Costa do Marfim, testando protocolos abreviados de AZT em gestantes com
HIV/AIDS, mostraram eficácia na redução da transmissão de $50 \%(53,65)$. Infelizmente, as questōes éticas levantadas pela utilização de grupos placebos, nos quais um alto índice de transmissão vertical foi observada, ofuscaram em parte a importância destes resultados. Entretanto, a possibilidade de regimes profiláticos mais curtos e baratos pode ser uma alternativa para países em desenvolvimento sem condições estruturais e financeiras de implementar o protocolo completo ACTG076.

Três estudos, do mesmo grupo de pesquisa, publicados em 1998 avaliaram aspectos maternos e neonatais da transmissão vertical em coorte de gestantes $\mathrm{HIV}^{+} /$AIDS e neonatos em São Paulo. Estes estudos mostraram risco de transmissão perinatal de $16 \%$ entre gestantes $\mathrm{HIV}^{+} /$AIDS (58). Avaliando o efeito do aleitamento materno na transmissão vertical, entre as crianças amamentadas em mães HIV-1 ${ }^{+} /$AIDS o risco de transmissão foi de $21 \%$, enquanto no grupo de crianças que receberam alimentação artificial, o risco de transmissão foi de $13 \%$ (59). Os resultados destes estudos mostraram ainda que maior infectividade materna representa risco médio aumentado de transmissão por aleitamento materno (16).

O conhecimento dos fatores de risco para a transmissão vertical vem crescendo gradualmente; entretanto, existe uma necessidade urgente de se reforçar na prática a atenção aos casos de HIV/AIDS pediátrica nos países em desenvolvimento.

\section{DIAGNÓSTICO DE TRANSMISSÃO VERTICAL PELO HIV-1}

Atualmente busca-se ansiosamente uma técnica que sirva como "gold standard" - "padrão ouro" - para o diagnóstico precoce definitivo da infecção pelo HIV-1 em crianças infectadas por via perinatal. O diagnóstico precoce da infecção é crítico para identificar neonatos infectados que possam se beneficiar de intervenções terapêuticas e profilaxia de infecçōes oportunistas, cruciais para aumentar a sobrevida e a qualidade de vida em casos de AIDS pediátrica. Intervenção terapêutica precoce é fundamental para limitar a replicação viral e preservar o sistema imune. Por outro lado, evita-se expor desnecessariamente crianças sem diagnóstico definitivo a tratamentos terapêuticos e profiláticos que são caros, complexos e extremamente tóxicos. Além dos benefícios clínicos do diagnóstico precoce, este representa também um benefício social e familiar, pois abrevia a espera angustiante, que pode durar até 24 meses, para a obtenção do diagnóstico definitivo pelas técnicas sorológicas convencionais.

Para o diagnóstico da infecção pelo HIV-1 por transmissão vertical devem ser considerados parâmetros clínicos, imunológicos e virais. Os sintomas clínicos relacionados à infecção por HIV-1/AIDS fornecem diagnóstico em qualquer idade. Na ausência de sintomas, o diagnóstico pode sèr obtido pela detecção de resposta imune-humoral do neonato, específica para o HIV-1 através de testes sorológicos convencionais seriados ou pela 
demonstração direta ou indireta do HIV-1 por cultura viral, amplificação do material genético do HIV ou antigenemia p24.

Os anticorpos IgG específicos para antígenos do HIV representam um marcador sensível e específico de infecção em adultos e crianças, após os primeiros 24 meses de vida (19). Entretanto, o diagnóstico precoce da infecção pelo HIV-1 é difícil de ser obtido através das técnicas sorológicas convencionais, em virtude de a grande maioria delas ser baseada na detecção de anticorpos da classe IgG. Praticamente todas as crianças, filhas de mães infectadas, são soropositivas para o HIV-1 ao nascimento, devido à transferência transplacentária da IgG materna, embora não mais que $40 \%$ delas estejam infectadas. Pelas técnicas sorológicas convencionais é impossível distinguir os anticorpos maternos dos anticorpos sintetizados pelo recém-nascido em resposta à infecção pelo HIV-1. Os anticorpos da classe IgM, indicadores de infecção recente, ou não são produzidos pelos recémnascidos ou são detectados somente transitoriamente e contra uma gama limitada de epítopos virais $(23,47)$. As tentativas de se obter produção de anticorpos por células mononucleares in vitro demonstraram que esta parece ser menos específica, principalmente em crianças mais novas (2). O testes de ELISPOT, que detecta células produtoras de anticorpos in vitro, é uma técnica mais sensível, porém pode apresentar resultados falso-negativos em crianças com deficiência na produção de anticorpos (40). Além disto, algumas crianças infectadas podem negativar os anticorpos maternos e não apresentar produçãa dos próprios anticorpos por um período de até 12 meses (1). Existem relatos de crianças que, apesar de apresentarem soronegativação, permanecem com cultura de HIV-1 e antigenemia p24 repetidamente positivos $(38,44)$. Em crianças expostas ao HIV-1 durante a gravidez e não infectadas, os anticorpos maternos geralmente se tornam não detectáveis a partir dos 9 meses de idade, mas podem ocasionalmente persistir até 24 meses de idade (9).

Ensaios baseados na detecção de anticorpos das classes IgE e IgA específicas para HIV-1 - detectados por radioimuniensaio (RAST) e por método imunoenzimático - (ELISA), têm sido usados para diagnosticar a infecção pelo HIV-1 em neonatos. Estas classes de anticorpos apresentam a vantagem de não atravessar a barreira placentária; logo, a detecção de anticorpos IgA e IgE específicos para o HIV-1 no neonato sugere síntese de anticorpos pelo feto induzida pela presença do HIV-1 (35). Os ensaios que detectam IgE são considerados mais sensíveis do que os que detectam IgA que carece de sensibilidade para detectar infecção pelo HIV-1 em recémnascidos e nos primeiros meses de vida $(48,63)$. Uma forte associação entre altos níveis de IgA em crianças infectadas e a rápida progressão da doença foi demonstrada recentemente (39). A possibilidade de outros testes sorológicos que detectem $\operatorname{IgA}$ e IgE pode vir a representar uma alternativa simples, confiável e de baixo custo para o diagnóstico de crianças infectadas, principalmente em países em desenvolvimento. Contudo, o valor categórico destes testes para o diagnóstico não foi conclusivamente avaliado.

A cultura viral para HIV-1 requer infra-estrutura altamente complexa com condições de biossegurança máxima, que permitam manipular material biológico de alto risco, é extremamente laboriosa e o resultado pode demandar até quatro semanas de cultivo. Mesmo havendo disponibilidade, a cultura muitas vezes não é realizada em crianças devido ao fato de exigir um grande volume de sangue. Uma outra possibilidade para se detectar indiretamente a presença do HIV-1 é através do teste de antigenemia p24. O antígeno p24 do HIV-1 é uma proteína do capsídeo viral considerada um importante marcador biológico de replicação viral. Já se demonstrou que a antigenemia p24 elevada durante os primeiros 6 meses de vida pode ser um indicador de mau prognóstico (45). Os ensaios comercialmente disponíveis para a detecção da antigenemia p24 são menos sensíveis que a cultura viral, especialmente quando altos níveis de anticorpos anti-HIV-1 estão presentes levando à formação de imunecomplexos com antígeno p24, que pode passar a não ser detectado pelo teste (49). Os ensaios modificados para a detecção de antígeno p24, após dissociação de imunocomplexos com tratamento com ácido ( "p24-ICD after Immune Complex Dissociation"), apresentam apenas uma relativa melhora na sensibilidade do diagnóstico, não devendo ser usado isoladamente como indicador de infecção em crianças $(29,36)$.

A ausência de infecção em crianças pode ser deduzida a partir da sororreversão, ou seja, a obtenção de um teste de sorologia negativo durante estudo seqüencial de amostras inicialmente soropositivas. Todavia, um diagnóstico positivo de infeção pelo HIV-1 somente é possível a partir de teste de sorologia persistentemente positivo, realizado numa idade em que os anticorpos maternos não sejam mais detectáveis. Segundo as normas do CDC e Ministério da Saúde/98, recomenda-se a realização de testes confirmatórios como Western Blot e Imunofluorescência Indireta $(6,9)$.

Avanço tecnológico de Biologia Molecular, como a Reação em Cadeia de Polimerase (PCR), representa uma conquista importante para identificação, monitoramento e isolamento de patógenos causadores de doenças infecciosas. PCR é uma técnica que mimetiza a maneira que a natureza normalmente utiliza para duplicar o DNA. Concebida e convertida em realidade em 1985, PCR rapidamente se transformou em uma ferramenta fundamental para pesquisa, porque permite, a partir de uma amostra mínima, a detecção e a amplificação de quantidades de material genético suficientes para estudo. Nenhuma descoberta da biotecnologia recebeu uma aceitaçāo tão ampla, rápida e evidente como PCR, em virtude de sua alta eficácia, especificidade, sensibilidade e confiabilidade. Nos últimos anos, PCR se transformou numa técnica repleta de reagentes, equipamentos e protocolos altamente padronizados. Avanços significativos continuam a surgir dos 
laboratórios de pesquisa, entre eles procedimentos automatizados, enzimas aprimoradas e modalidades de PCR em fase sólida.

O DNA é mais freqüentemente encontrado na forma de dupla-hélice constituída de fitas complementares. A técnica de PCR se inicia a partir da separação das fitas de DNA por aquecimento (figura 1). Quando resfriadas, as fitas simples de DNA contendo seqüências de HIV proviral se reanelam
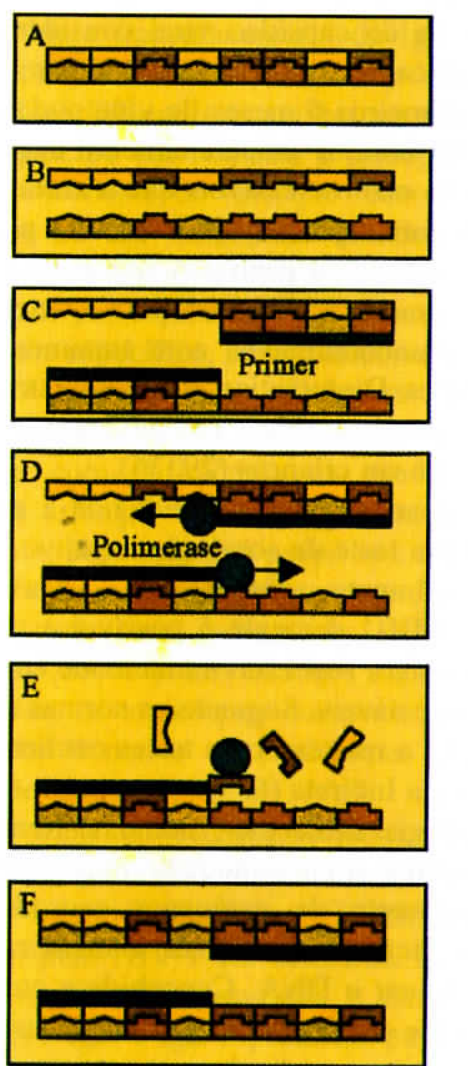

Figura 1. A duplicaçāo do DNA se inicia a partir de DNA dupla fita a ser amplificado (A). Quando a solução é aquecida a aproximadamente $95^{\circ} \mathrm{C}$, ocorre o rompimento das pontes de hidrogênio, liberando duas fitas simples de DNA (B). Quando solução é resfriada (B). Quando soluçáo é resfriada para $50-65^{\circ} \mathrm{C}$ os primers ou sondas sintéticas se anelam de forma complementar a regiäo alvo a ser amplificada de cada fita (C). A $72^{\circ} \mathrm{C}$ a enzima DNA-polimerase capta os deoxinucleotídeos trifosfato livres em solução que complementa a próxima posição não pareada da fita molde de DNA, estendendo os primers ligados em uma única direção (D e E). Os produtos são duas moléculas novas de DNA dupla fita, idênticas à original ( $\mathrm{F}$. Reaçōes cíclicas repetitivas levam Reçoes ciclicas repetitivas levam a mécento exponencial das moléculas de DNA alvo, pois os produtos de cada ciclo se tornam
moldes para o ciclo seguinte $(G)$.

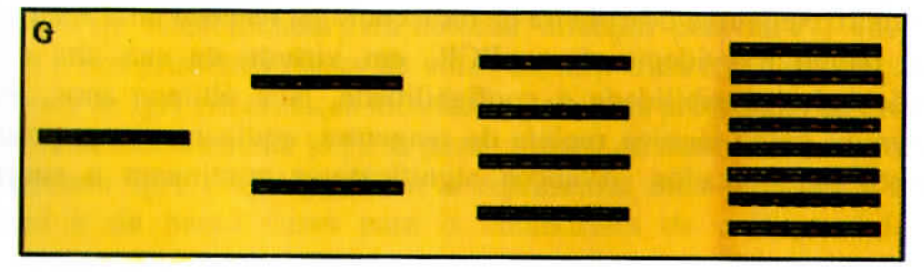

com pequenas seqüências sintéticas de nucleotídeos específicas para HIV. Estas seqüências, ou primers, são exatamente complementares à região alvo do DNA que se pretende amplificar. A esta reação são adicionados deoxinucleotídeos trifosfatos, que constituem os blocos de construção do DNA, tampões e a enzima termorresistente denominada DNA polimerase. O aquecimento da mistura separa as fitas-moldes de DNA e, em diferentes temperaturas, o resto dos componentes na mistura, primers e deoxinucleotídeos trifosfato, espontaneamente se organizam, construindo uma nova fita complementar para cada molde original de DNA. Em suma, o método consiste de ciclos repetitivos de aquecimento para ocorrer a desnaturação, com resfriamento para promover anelamento com as sondas complementares e síntese de uma nova molécula de DNA a partir da atividade da enzima DNA polimerase, que catalisa a síntese de novas fitas de DNA pela adição de nucleotídeos complementares à fita simples de DNA. Após cada ciclo de amplificação, a quantidade de DNA duplica, resultando em acumulação exponencial da seqüência alvo. Se iniciarmos o processo com uma molécula de DNA, após 30 ciclos de amplificação teremos aproximadamente um bilhão de cópias de DNA (15). Por esta propriedade de amplificação extraordinária da técnica, todo cuidado deve ser tomado pois mesmo a contaminação com quantidades mínimas de material viral pode produzir um resultado falso-positivo. O risco de contaminação pode ser minimizado usando-se ambientes distintos para o preparo dos reagentes, para a reação de PCR e para a análise do produto amplificado. A técnica de PCR também pode ser utilizada para a amplificação de RNA a partir da transcrição reversa do RNA em DNA complementar-cDNA, que é então empregado para a amplificação enzimática de forma idêntica à descrita para o DNA genômico. A detecção do material amplificado pode ser feita após separação por eletroforese e visualização por coloração com brometo de etídio por autoradiografia e por métodos imunoenzimáticos.

A utilização da técnica de PCR para diagnóstico de transmissão perinatal pelo HIV-1 foi introduzida depois da metade da década de 80 (11, $13,17,26,40,42,43,50)$. O HIV é um retrovírus que para completar seu ciclo replicativo, após infectar a célula alvo, os linfócitos $\mathrm{T}^{\mathrm{C}} \mathrm{CD}_{4}{ }^{+} \mathrm{ou}$ macrófagos $\mathrm{CD}_{4}{ }^{+}$, converte o RNA viral em DNA pela ação da enzima viral transcriptase reversa. O DNA proviral gerado é subseqüentemente integrado ao genoma da célula infectada pela ação da,enzima viral integrase. A técnica de PCR para o HIV-1 envolve a detecção de RNA viral proveniente de vírions ou partículas virais presentes no plasma, ou do DNA proviral obtido de células mononucleares infectadas. A técnica de PCR qualitativa detecta e amplifica o DNA proviral e a técnica de PCR quantitativa amplifica cDNA ou transcrito reverso de RNA viral. Como o PCR permite a amplificação exponencial do material inicial, esta pode ser realizada a partir de pequenos 
volumes de sangue, sendo adequada para o uso em neonatos. Além desta vantagem, a técnica pode ser concluída em apenas um dia de trabalho.

O teste de PCR qualitativo tem sido utilizado para o diagnóstico de crianças pois pode ser capaz de detectar os raros linfócitos $\mathrm{T}$ infectados nos recém-nascidos e amplificar o DNA proviral do HIV-1. A confirmação da especificidade e da sensibilidade da técnica de PCR para HIV-1 levaram a sua incorporação nas normas recomendadas pelo CDC em 1994, para diagnóstico precoce da infecção pelo HIV.

A técnica de PCR na infeção pediátrica pelo HIV-1 tem o potencial de definir o tempo em que a transmissão vertical ocorreu, se intra-útero ou intrapartum $(8,24)$. A definição do tempo no qual a transmissão ocorreu é importante para definir a conduta terapêutica e indicar a taxa de progressão da doença. A progressão da infeção para AIDS ou morte foi demonstrada ser 2,5 vezes maior entre as crianças infectadas intra-uterinamente $(27,32)$. A detecção de seqüências de DNA provirais de HIV-1 em amostras de sangue cuidadosamente coletadas de cordão umbilical ou de punção venosa do recém-nascido nas primeiras 48 horas sugere transmissão intra-uterina. Risco de contaminação do cordão umbilical com células maternas causando resultados de PCR falsos-positivos não são muito freqüentes, indicando que sangue de cordão umbilical pode ser útil na triagem inicial da infecção pelo HIV-1 (26). Testes de PCR negativos para HIV-1 na primeira semana e positivos mais tardiamente sugerem transmissão intrapartum. Estes critérios se baseiam no fato de que um intervalo de tempo entre a infecção e a detecção é exigido para que ocorra um número mínimo de ciclos de infecção celular e de replicação viral necessários para produzirem níveis virais detectáveis por PCR.

Um teste viral positivo em qualquer idade é indicativo de infecção pelo HIV-1. Como medida de segurança contra possíveis falhas nos procedimentos laboratoriais, a convenção é classificar uma criança como infectada pelo HIV-1 somente após dois testes positivos obtiḍos em amostras biológicas diferentes. Os testes virais têm sido suficientemente sensíveis para permitir a exclusão da infecção tendo como base a obtenção de um resultado negativo; contudo, a sensibilidade do teste de PCR para DNA viral tem sido relatada como particularmente baixa no primeiro mês de vida $(11,13,17,26$, $40,42,43,50)$, podendo gerar resultados falsos-negativos e justificando a exigência de dois testes positivos, em amostras biológicas diferentes obtidas após determinado intervalo de tempo.

Cautela deve ser tomada na interpretação de apenas um resultado de PCR positivo. Recentemente, 43 casos originalmente descritos como "infecção transitória por HIV", por terem apresentado um único resultado positivo por cultura ou por PCR, seguido de impossibilidade de detecção em múltiplas ocasiões subseqüentes ou de sororreversão, foram reavaliados. Estudos genéticos realizados com estas amostras não confirmaram a ocorrência de "infecção transitória", indicando que os resultados positivos que não puderam ser subseqüentemente confirmados foram causados por falhas humanas nos procedimentos laboratoriais (21).

Uma revisão meta-analítica dos resultados de 32 artigos publicados entre 1992-94, nos quais o PCR de DNA proviral foi utilizado para o diagnóstico de neonatos e crianças, relatou uma mediana de sensibilidade de $91,6 \%$ e mediana de especificidade do teste de $100 \%$. Um teste laboratorial considerado perfeito é aquele que apresenta taxa de resultados falsospositivos e falsos-negativos igual a zero e uma taxa máxima de sensibilidade e especificidade de $100 \%$. À medida em que se aumenta a especificidade de um teste laboratorial, a sensibilidade deste diminui. De acordo com os resultados desta revisão, a sensibilidade e a especificidade do teste de PCR para o diagnóstico de crianças variam com a idade. A sensibilidade do teste é menor em neonatos com menos de 30 dias. A sensibilidade e a especificidade máximas do teste em neonatos são de $93,3 \%$, o que corresponde a uma taxa de falsos-positivos e falsos-negativos de $6,7 \%$. A sensibilidade e a especificidade máximas em crianças são de $98,2 \%$, o que corresponde a uma taxa de falsos-positivos e falsos-negativos de $1,8 \%$. A menor sensibilidade do teste no período neonatal é compatível com a hipótese de que a maioria dos casos de transmissão vertical ocorre próximo ao parto ou no momento do parto propriamente dito. Desta forma, a sensibilidade diminuída do teste nos primeiros 30 dias após o parto reflete o pequeno número de cópias de DNA viral neste período, melhorando a sensibilidade à medida em que há aumento da replicação viral e conseqüente elevação do número de cópias de DNA viral. Um teste de PCR negativo reduz a probabililidade de doença para $0.2 \%$ - $2.4 \%$, dando indícios substanciais, mas não definitivos, de que a criança não está infectada pelo HIV-1. O valor preditivo positivo do teste de PCR qualitativo que detecta DNA proviral varia de $56 \%$ a $95 \%$, dependendo das circunstâncias clínicas.

Estudos avaliando a detecção de HIV-1 RNA no plasma, que aumenta rapidamente durante a fase aguda da infecção, sugerem a detectação mais precocemente deste do que HIV-1 DNA $(13,57)$. Se outros estudos confirmarem maior sensibilidade e especificidade dos ensaios de PCR para HIV-1 RNA durante o primeiro ano de vida, este teste poderá fornecer um diagnóstico mais precoce da infecção do que o atualmente possível, o que representará uma melhoria na capacidade de distinguir o momento de transmissão, se intra-uterina ou intrapartum.

Devido à sensibilidade, especificidade e rapidez para obtenção do resultado, o teste de PCR é considerado um dos melhores testes disponíveis para o diagnóstico precoce da infeçção pelo HIV-1 em recém-nascidos e crianças. A avaliaçăo da sensibilidade e da especificidade do PCR para o diagnóstico da infecção pelo HIV-1 em crianças é dificultada pela inexistência de um teste "gold standard". Paradoxalmente, é exatamente a Vol. 28 (1): 26-40. jan.-jun. 1999 
falta de tal teste que torna o teste de PCR a técnica mais promissora e atrativa para o diagnóstico precoce da infecção pelo HIV-1 em crianças expostas durante a gestação.

\section{SUMMARY}

Pediatric AIDS: Advances in the prevention and diagnosis

Pediatric AIDS is one of the most challenging diseases, involving medical, family, social and economic aspects. Heterosexual transmission represents an increasing route of HIV-1 dissemination leading to increased numbers of infected women of child-bearing age and perinatally HIV-1 infected children. Maternal's clinical, immunologic and virological status, obstetrical factors, breastfeeding and mother-to-child HLA-1 concordance have been shown to be associated with perinatal HIV-1 transmission. Once infected by HIV-1, children may evolve rapidly to AIDS usually during the first year of life, differently from adults, who may remain symptom-free for several years. Early identification of HIV-1 infection in infant is fundamental for the prompt introduction of antiretroviral therapy and prophylactic regimens for opportunistic infections. Serial serological tests, viral culture, p24 detection and HIV-1 genomic amplification have been employed for the diagnosis of perinatal HIV-1 infection. In order to minimize potencial interferences of maternal IgG antibodies which can persist for up to 24 months, detection of virus specific $\operatorname{IgE}$ and $\operatorname{IgA}$ antibodies are currently under study, but their exact value has not been defined. HIV-1 culture is laborious, expensive, timeconsuming and requires maximun biosafety levels. The detection of p24 antigen is less sensitive than HIV-1 culture, even after imunecomplex dissociation, therefore HIV-1 diagnosis should not be based on p24 antigen detection alone. The Polimerase Chain Reaction (PCR) has been demonstrated to be a specific, sensitive and reliable technique for the identification of HIV-1, promoting rapid viral genome amplification and detection. The assessment of specificity and sensitivity of HIV-1 PCR for pediatric infections has been hampered by the absence of a "gold standard" technique. Paradoxically, it is the absence of such a "gold standard" that makes PCR the most promising and attractive technique for early definitive diagnosis of perinatally HIV-1 infected infants.

KEY WORDS: HIV. Serological and molecular diagnosis of HIV-1 infection. Pediatric AIDS. Vertical transmission. PCR.

\section{REFERENCIAS BIBLIOGRÁFICAS}

1. Aiuti F, Luzi G, Mezzarona I, Scano G \& Papetti C. Delayed appearence of HIV infection in children. Lancet $2: 858,1987$.

2. Amadori A, DeRossi A, Chieco-Bianchi L, Giaquinto C, De Maria A \& Ades AE. Diagnosis of human immunodeficiency virus 1 infection in infants: in vitro production of virusspecific antibody in lymphocytes. Pediatr Infect Dis J 9:26-30, 1990.
3. Balter, M. On world AIDS day, a shadow looms over Southern Africa. Science, 282: 17901791, 1998

4. Bamji M, Thea DM, Weedon J, Krasinski K, Matheson PB, Thomas P, Lambert G, Abrams EJ, Steketee R \& Heagarty M. Prospective Study of Human Immunodeficiency Virus 1related Disease Among 512 Infants Born to Infected Women in New York City. Pediatr Infect Dis J 15:891-898, 1996.

5. Barnhart HX, Caldwell MB, Thomas P, Mascola L, Ortiz I, Hsu HW, Schulte J, Parrot R, Maldonado Y \& Byers R . Natural history of human immunodeficiency virus disease in perinatally infected children: an analysis from the pediatric spectrum of disease project. Pediatr 97: 710-716, 1996.

6. Boletim Epidemiológico, Ministério da Saúde, Programa Nacional Doenças Sexualmente Transmissíveis/AIDS. Ano XII (01), 1999.

7. Brady MT, McGrath N, Brouwers P, Gelber R, Fowler MG, Yogev R, Hutton N, Bryson YJ, Mitchell CD, Fikrig S, Borkowsky W, Jimenez E, McSherry G, Rubinstein A, Wilfert CM, McIntosh K, Elkins MM \& Weintrub PS. Randomized Study of the Tolerance and Efficacy of High- Versus Low-Dose Zidovudine in Human Immunodeficiency VirusInfected Children with mild to moderate Symptoms (AIDS Clinical Trail Group 128). J Infect Dis 173:1097-1106, 1996.

8. Bryson YJ, LuzuriagaK, Sullivan JL \& Wara DW. Proposed definitions for in utero versus intrapartum transmission of HIV-1. N Engl J Med 327:1246-1247, 1992.

9. Centers for Disease Control and Prevention. 1994 Revised classification system for human immunodeficiency virus infection in children less than 13 years of age. MMWR 43:1-9, 1994.

10. Centers for Disease Control and Prevention. Administration of Zidovudine During late Pregnancy and Delivery to Prevent Perinatal HIV Transmission - Thailand, 1996-1998. MMWR 47: 151-154, 1998

11. Chadwick EG, Yogev R, Kwok S, Sninsky JJ, Kellog DE \& Wollinsky SM. Enzymatic amplification of the human immunodeficiency virus in peripheral blood mononuclear cells from pediatric patients. $J$ Infect Dis 160:954-959, 1989.

12. Connor, E. M.; Sperling, R. S.; Gelber, R.; Kiselev, P.; Scott, G.; O’Sullivan, M. J.; VanDyke, R.; Bey, M. Shearer, W; Jacobson, R. L; Jimenez, E; Coombs, R; Elkins, M. Moye, J.; Stratton, P. \& Balsley, J. Reduction of maternat-infant transmission of M.; Moye, J; Stristion of human immunodeficiency virus type 1 with zidovudine treatment. $N$ Engl $J$ Med,
331:1173-1180,1994.

13. Cunningham CK, Charbonneau TT, Song K, Patterson D, Sullivan T, Cummins T \& Poiesz B. Comparison of human immunodeficiency virus 1 DNA polymerase chain reaction and qualitative and quantitative RNA polymerase chain reaction in human immunodeficiency virus 1-exposed infants. Pediatr Infect Dis J 18:30-35, 1999

14. Dickover, R. E.; Garratty, E. M.; Herman, S. A.; Sim, M.; Plaeger, S.; Boyer, P. J.; Keller, M.; Deveikis, A.; Stiehm, R. \& Bryson, Y. J. Identification of levels of maternal HIV-1 RNA associated with risk of perinatal transmission. JAMA, 275: 599-605, 1996.

15. Dragon EA. Polymerase Chain Reaction. Scient Amer 278:112, 1998.

16. Dunn DT, Tess BH, Rodrigues LC \& Ades AE. Mother-to-child transmission of HIV: implications of variation in maternal infectivity. AIDS 12:2211-2216, 1998.

17. Dunn DT. A review of statistical methods for estimating the risk of vertical human immunodeficiency virus transmission. Intern J Epidemiol 27:1064-1067, 1998.

18. Ekpini ER, Wiktor SZ, Satten GA, Adjorlolo-Johnson GT, Sibailly TS, Ou C, Karon JM, Brattegaard K, Whitaker JP, Gnaore E, De Cock KM \& Grenıberg AE. Late Postnatal Mother-to-Child Transmission of HIV-1 in Abidjan, Cote d'lvoire. Lancet, 349:10541059, 1997.

19. European Collaborative Study. Risk factors for mother-lo-child transmission of HIV-1. Lancet, 339:1007-1012. 1992. 
20. European Mode of Delivery Collaboration. Elective caesarean-section versus vaginal delivery in prevention of vertical HIV-1 transmission: a randomised clinical trial. Lancet, 353: 1035-1039. 1999.

21. Frenkel LM, Mullins JI, Learn GH, Manns-Arcuino L., Herring BL, Kalish ML, Steketee RW, Thea DM, Nichos JE, Liu S-L, Harmache A, He X, Muthui D, Madan A, Hood D, Haase AT, Zupanic M, Staskus $K$, Wolinsky S, Krogst P, Z hoo J, Chen I Koup R, Ho D, Kor D, Korber B, Apple RJ, Cooms RW, Pawa S, and Robers Jr. NJ. Genetic evaluation

22. Gellert GA, Durfee MJ, Berkowitz CD, Higgins KV \& Tubiolo VC. Situational and socidemographic characteristics of children infected with human immunodeficiency virus from pediatric sexual abuse. Pediatrics, 91:39-44, 1993.

23. Johnson JP, Nair P \& Alexander S. Early diagnosis of HIV infection in the neonate. $N$ Engl JMed, 316: 273-274, 1987.

24. Kalish LA, Pitt J, Lew J, Landesman S, Diaz C, Hershow R, Hollinger FB, Pagano M, Smeriglio V \& Moye J. Definig the time of fetal or perinatal acquisition of human immunodeficiency virus type 1 infection on the basis of age at first positive culture. $J$ Infect Dis, 175:712-715, 1997.

25. Karlsson K, Massawe A, Urassa E, Kawo G, Msemo G, Kazimoto T, Lyamuya E, Mbena E, Urassa W, Bredberg-Ráden U, Mhalu F \& Biberfeld G. Late Postnatal transmission of human immunodeficiency virus type 1 infection from mothers to infants in Dar es Salaam, Tanzania. Pediatr Infect Dis J, 16:963-967, 1997.

26. Kovacs A, Xu Jiaao, Rasheed S, Li X-L, Kogan T, Lee M, Liu C \& Chan L. Comparison of a rapid nonisotopic polymerase chain reaction assay with four commonly used methods for early diagnosis of human immunodeficiency virus type 1 infection in neonates and children. Pediatr Infect Dis J, 14:948-954, 1995.

27. Kuhn L, Steketee RW, Weedon J, Abrams EJ, Lambert G, Bamji M, Schoembaun E, Farley J, Nesheim SR, Palumbo P, Simonds RJ \& Thea DM. Distinct risk factors for intrauterine and intrapartum human immunodeficiency virus transmission and consequences for disease progression in infected children. J Infect Dis, 179:52-58, 1999.

28. Landesman, S. H.; Kalish, L. A.; Burns, D. N.; Minkoff, H.; Fox, H. E.; Zorrilla, C.; Garcia, P.; Fowler, M. G.; Mofenson, L. \& Tuomala, R. Obstetrical factors and the transmission of human immunodeficiency virus type 1 from mother to child. $N$ Engl J Med. 334: 1617-1623. 1996

29. Lewis DE, Adu Oppong A, Hollinger FB, Rosenblatt HM, Hanson IC, Reuben JM, Kline MW, Kozinetz CA \& Shearer WT. Sensitivity of imune-complex-dissociated p24 antigen testing for early detection of human immunodeficiency virus in infants. Clin antigen testing for early detection

30. MacDonald KS, Embree J, Njenga S, Nagelkerke NJD, Ngatia I, Mohammed Z, Barber BH, Ndinya-Achola J, Bwayo J \& Plummer FA. Mother-child class I HLA concordance increases perinatal human immunodeficiency virus type 1 transmission. $J$ Infect Dis, 177:551-556, 1998.

31. Mandelbrot, L.; Le Chenadec, J.; Berrebi, A. Bongain, A.; Bénifla, JL.; Delfraissy, JF.; Blanche, S. \& Mayaux, MJ. Perinatal HIV-1 transmission: Interaction between zidovudine prophylaxis and mode of delivery in the french perinatal cohort. JAMA, 280:55-60. 1998.

32. Mayaux MJ, Burgard M, Teglas JP, Cattalorda J, Krivine A, Simon F, Puel J, Tamalet C, Dormont D, Masquelier B, Doussin A, Rouzioux C, and Blanche S. Neonatal characteristics in rapidly progressive perinatally acquired HIV-1 disease. JAMA, 275:606-610, 1996.

33. Mayaux, M. J.; Dussaix, E.; Isopet, J.; Rekacewicz, C.; Mandelbrot, L.; Ciraru-Vigneron, N.; Allemon, M. C.; Chambrin, V.; Katlama, C.; Delfraissy, J. F. \& Puel, J. Maternal virus load during pregnancy and mother-to-child transmission of human immunodeficiency virus type 1: The French Perinatal Cohort Studies. J Infect D, 175: $172-175,1997$
34. McIntosh K, Shevitz A, Zaknun D, Kornegay J, Chatis P, Karthas N \& Burchett SK. Ageand Time-related Changes in Extracellular Viral Load in Children Vertically Infected by Human Immunodeficiency Virus. Pediatr Infect Dis J, 15:1087-1091, 1996.

35. Miguez-Burbano MJ, Hutto C, Shor-Posner G, Scott G, Lopez V, Lai S, Lai H, Fletcher M \& Baum MK. IgE-based assay for early detection of HIV-1 infection in infants. Lancet, 350:782-783, 1997.

36. Miles SA, Baldern E, Magpantay L, et al. Rapid serologic testing with imune-complexdissociated HIV p24 antigen for early detection of HIV infection in neonates. $N$ Engl $J$ Med, 328:297-302, 1993

37. Minkoff, H.; Burns, D. N.; Landesman, S.; Youchah, J.; Goedert, J. J.; Nugent, R. P.; Muenz, L. R. \& Willoughby, A. D. The relationship of the duration of ruptured membranes to vertical transmission of human immunodeficiency virus. Am J Obstet Gynecol, 173: 585-589. 1995.

38. Mok JQ, DeRossi A, Ades AE, Giaquinto C, Grosch-Wörner I \& Peckham CS. Infants born to mothers seropositive for human immunodeficiency virus. Preliminary findings from a multicentre European study. Lancet, 1:1164-1168, 1987.

39. Moodley D, Coovadia HM, Bobat RA \& Sullivan JL. HIV-1 specific immunoglobulin A antibodies as an effective

40. Nesheim S, Lee F, Kalish ML Ou C-Y, Sawyer M, Clark S, Meadows L Grimers V, Simonds RJ \& Nahmias A. Diagnosis of perinatal human immunodeficiency virus infection by polymerase chain reaction and $\mathrm{p} 24$ antigen detection after immune complex infection by polymerase chain reaction and p24 antigen detection after immune
dissociation in an urban community hospital. $J$ Infect Dis, 175:1333-1336, 1997.

41. Nesheim S, Lee F, Sawyer M, Jones D, Lindsay M, Slade B, Shaffer N, Holmes R, Ashby $R$, Grimes V. Diagnosis of human immunodeficiency virus infection by enzyme-linked immunospot assays in a prospectively followed cohort of infants of human immunodeficiency virus-seropositive women. Pediatr Infect Dis J, 11:635-639, 1992

42. Ou C-Y, Kwok S, Mitchell SW, et al. DNA amplification for direct detection of HIV-1 in DNA of peripheral blood mononuclear cells. Science, 239:295-297, 1988.

43. Owens DK, Holodniy M, McDonald TW, Scott J, Sonnad S. A meta-analytic evaluation of the polymerase chain reaction for the diagnosis of HIV infection in infants. JAMA, 275:1342-1347, 1996.

44. Pahwa R, Good RA \& Pahwa S. Prematurity, hypogamaglobulinemia, and neuropathology with human immunodeficiency virus (HIV) infection. Proc Natl Acad Sci USA, 84:38263830, 1987.

45. Papaevangelou V, Pollack H, Riguad M, Arlievsky N, Lu ML, Rochford G, Krasinski K \& Borbowsky W. The amount of early p24 antigenemia and not the time of first detection of virus predicts the clinical outcome of infants vertically infected with human immunodeficiency virus. $I$ Infect Dis, 173:574-578, 1996

46. Pitt, J.; Brambilla, D.; Reichelderfer, P.; Landay, A.; McIntosh, K.; Burns D.; Hillyer, G. V.; Mendez, H. \& Fowler, M. G. Maternal immunologic and virologic risk factors for infant human immunodeficiency virus type 1 infection: findings from the women and infants transmission study. $J$ Infect $D, 175: 567-575.1997$.

47. Pyun KH, Ochs HD, Dufford MTW \& Wedgwood RJ. Perinatal infection with human immunodaficiency virus. $N$ Engl J Med, 317:611-614, 1987.

48. Quinn TC, Kline RI, Halsey N, Hutton N, Ruff A, Butz A, Boulos R, Modlin JF. Early diagnosis of perinatal HIV infection of viral especific IgA antibodies. JAMA, 266:3439$3442,1991$.

49. Rogers M, Ou C, Kilbourne B \& Schochetman G. Advances and problems in the diagnosis of human immunodeficiency virus infection in infants. Pediatr Infect Dis $J, 10: 523-531$, 1991

50. Rogers MF, Ou C-Y, Rayfield M, Thomas PA, Schoembaum EE, Abrams E, Krasinski K, Selwyn PA, Moore J, Kaul A, Grimm KT, Bamji M \& Schochetman G. Use of the polymerase chain reaction for early detection of the proviral sequences of human (1): 26-40. jan.-jun. 1999 
immunodeficiency virus in infants born to seropositive mothers. $N$ Engl J Med, 320:1649-1654, 1989.

51. Ryder, R. W.; Nsa, W.; Hassig, S. E.; Behets, F.; Rayfield, M.; Ekungola, B.; Nelson, A. M.; Mulenda, U.; Francis, H.; Mwandagalirwa, K.; Davachi, F.; Rogers, M.; Nzilambi, N.; Greenberg, A.; Mann, J.; Quinn, T. C.; Piot, P. \& Curran, J. W. Perinatal transmission of the human immunodeficiency virus type 1 to infants of seropositive women in Zairc. $N$ Engl J Med, 320: 1637-1642. 1989.

52. Scoll GB, Hutto C, Makuch RW, Mastrucci MT, O'Connor T, Mitchell CD, Trapido EJ \& Parks WP. Survival in Children with Perinatally Acquired Human Immunodeficiency Virus Type 1 Infection. N Engl J Med, 321:1791-1796, 1989.

53. Shaffer N, Chuachoowong R, Mock PA, Bhadrakom C, Siriwasin W, Young NL, Chotpitayasunondh T, Chearskul S, Roongpisuthipong A, Chinayon P, Karon J, Mastro TD \& Simonds RJ. Short-course zidovudine for perinatal HIV-1 transmission in Bangkok, Thailand: a randomised controlled trial. Lancet, 353:773-780, 1999.

54. Shearer WT, Quinn TC, LaRussa P, Lew JF, Mofenson L, Almy S, Rich K, Handelsman E, Diaz C, Pagano M, Smeriglio V \& Kalish LA. Viral Load and Disease Progression in Inafants Infected with Human Immunodeficiency Virus Type 1. N Eng J Med, 336:13371342, 1997.

55. Sperling, R. S.; Shapiro, D. E.; Coombs, R. W.; Todd, J. A.; Herman, S. A.; McSherry, G. D.; O’Sullivan, M. J.; Van Dyke, R. B.; Jimenez, E.; Rouzioux, C.; Flynn, P. M. \& Sullivan, J. L. Maternal viral load, zidovudine treatment, and the risk of transmission of human immunodeficiency virus type 1 from mother to infant. $N$ Engl $J$ Med, 335:16211629, 1996.

56. St. Louis, M. E.; Kamenga, M.; Brown, C.; Nelson, A. M.; Manzila, T.; Batter, V.; Behets, F.; Kabagabo, U.; Ryder, R. W.; Oxtoby, M.; Quinn, T. C. \& Heyward W. L. Risk for perinatal HIV-1 transmission according to maternal immunologic, virologic, and placental factors. JAMA, 269: 2853-2859. 1993.

57. Steketee RW, Abrams EJ, Thea DM, Brown TM, Lambert G, Orloff S, Weedon J, Bamji M, Schoembaun EE, Rapier J \& Kalish ML. Early detecion of perinatal human immunodeficiency virus (HIV) type 1 infection using HIV RNA amplification and detection. J Infect Dis, 175:707-711, 1997.

58. Tess BH, Rodrigues LC, Newell ML, Dunn DT \& Lago TD. Breastfeeding, genetic, obstetric and other risk factors associated with mother-to-child transmission of HIV-1 in Sao Paulo State, Brazil. AIDS, 12:513-520, 1998.

59. Tess BH, Rodrigues LC, Newell ML, Dunn DT \& Lago TD. Infant feeding and risk of mother-to-child transmission of HIV-1 in Sāo Paulo State, Brazil. AIDS, 19:189-194, 1998.

60. The European Collaborative Study. Caesarean section and risk of vertical transmission of HIV-1 infection. Lancet, 343: 1464-1467. 1994.

61. The European Collaborative Study. Natural History of Vertically Acquired Human Immunodeficiency Virus-1 Infection. Pediatr, 94: 815-819, 1994.

62. Tovo PA, Martino M, Gabiano C, Cappello N, D'Elia R, Loy A, Plebani A, Zuccotti GV, Dallacasa P, Ferraris G, Caselli D, Fundaro C, D'Argenio P, Galli L, Principi N, Stegagno M, Ruga E \& Palomba E. Prognostic Factors and Survival in Children with Perinatal HIV-1 Infection. Lancet, 339: 1249-1253, 1992.

63. Weiblen BJ, Lee FK, Cooper ER, Landesman SH, McIntosh K, Harris JÁ, Nesheim S, Mendez H, Pelton ST, Nahmias AJ. Early diagnosis of HIV infection in infants by detection of IgA HIV antibodies. Lancet, 335:988-990, 1990.

64. WHO/UNAIDS. Report on the global HIV/AIDS epidemic. June 1998.

65. Wiktor SZ, Ekpini E, Karon JM, Nkegasong J, Maurice C, Severin ST, Roels TH, Kouassi MK, Lackritz EM, Coulibaly IM \& Greenberg AE. Short-course oral zidovudine for prevention of mother-to-child transmission of HIV-1 in Abidjan, Côte d'Ivoire. Lancet, 353:781-785, 1999. 